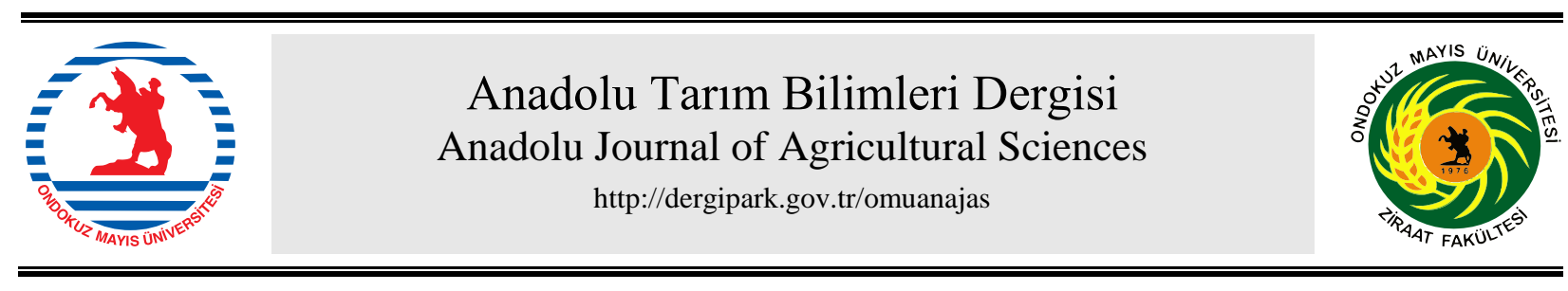

Araştırma/Research

Anadolu Tarım Bilim. Derg./Anadolu J Agr Sci, 33 (2018)

ISSN: 1308-8750 (Print) 1308-8769 (Online)

doi: 10.7161/omuanajas.336108

\title{
Tritikale genotiplerinin tane verimi ve bazı kalite özellikleri
}

\author{
Zeki Mut*, Özge D.Erbaş Köse \\ Bozok Üniversitesi Ziraat Fakültesi Tarla Bitkileri Bölümü \\ *Sorumlu yazar/corresponding author: zeki.mut@bozok.edu.tr \\ Geliş/Received 25/08/2017～Kabul/Accepted 03/01/2018
}

\begin{abstract}
ÖZET
Dünyada tritikale insan gıdası ve hayvan yemi olarak değişik şekillerde kullanılmaktadır. Özellikle, marjinal alanların değerlendirilmesinde ve artan yem açığının kapatılmasında önemli bir alternatif bitki olarak karşımıza çıkmaktadır. Bu çalışma, Yozgat ekolojik koşullarında tritikale genotiplerinin verim ve kalite yönünden durumlarını belirlemek amacıyla 2012-2015 yılları arasında üç yıl süreyle yürütülmüştür. Deneme tesadüf blokları deneme desenine göre dört tekrarlamalı olarak gerçekleştirilmiştir. Varyans analiz sonucunda incelenen tüm özellikler bakımından yıl, genotip ve yıl $\times$ genotip interaksiyonları önemli bulunmuştur. Yılların ortalaması olarak bitki boyu (BB) 84.1-107.6 cm, metrekaredeki başak sayıs (MBS) 288.0-508.7 adet, hasat indeksi (HI) \% 28.6-38.8, tane verimi (TV) 230.4- 366.1 kg da-1, bin tane ağırlığı (BTA) 29.0-40.3 g, hektolitre ağırlığ (HA) $66.7-71.3 \mathrm{~kg}$, protein oranı (PO) \% 12.3-14.8, yağ oranı (YO) \% 1.11-1.76, nişasta oranı (NO) \% 62.266.2, kül oranı (KO) \% 1.68-2.17, ADF \% 2.437-3.585, NDF \% 17.5-19.1, Zeleny sedimantasyon değeri (ZSD) 20.3-30.9 ml, yaş gluten (YG) \% 22.4-26.5, K \% 0.525-0.668, Mg \% 0.129-0.150 ve P \% 0.366-0.408 arasında değişmiştir. En yüksek tane verimi $14\left(351.7 \mathrm{~kg} \mathrm{da}^{-1}\right), 15\left(359.7 \mathrm{~kg} \mathrm{da}^{-1}\right), 23\left(340.2 \mathrm{~kg} \mathrm{da}^{-1}\right)$ ve 24 $\left(366.1 \mathrm{~kg} \mathrm{da}^{-1}\right)$ numaralı tritikale genotiplerinden elde edilmiştir. TV ile BB $\left(\mathrm{r}=0.422^{* *}\right)$, MBS $\left(\mathrm{r}=0.405^{* *}\right)$, HI $\left(\mathrm{r}=0.548^{* *}\right)$, BTA $\left(\mathrm{r}=0.479^{* *}\right)$, HA $\left(\mathrm{r}=0.559^{* *}\right)$ ve $\mathrm{P}\left(\mathrm{r}=0.129^{*}\right)$ arasinda önemli ve olumlu, PO $\left(\mathrm{r}=-0.238^{* *}\right)$, YO $\left(\mathrm{r}=-0.126^{*}\right), \operatorname{ADF}\left(\mathrm{r}=-0.119^{*}\right)$, NDF $\left(\mathrm{r}=-0.566^{* *}\right), \mathrm{ZSD}(\mathrm{r}=-0.304 * *)$ ve YG $\left(\mathrm{r}=-0.496^{* *}\right)$ arasinda önemli ve olumsuz ilişki tespit edilmiştir. Biplot analiz grafiğine göre 23 numaralı genotip tane verimi yanında; $\mathrm{BB}, \mathrm{BTA}, \mathrm{ZSD}, \mathrm{YG}, \mathrm{PO}, \mathrm{K}, \mathrm{P}$ ve $\mathrm{Mg}$ gibi özellikler bakımından da ön plana çıkmıştır. Tane verimi bakımından 7 numaralı genotip tüm çevrelere iyi uyum, 3, 4, 9 ve 21 numaralı genotipler tüm çevrelere orta uyum göstermiştir.
\end{abstract}

\section{Grain yield and some quality properties of triticale genotypes}

\section{ABSTRACT}

Triticale is used for different targets as human food and animal feed in the world. In particular, Triticale is an important alternative crop to use of marginal areas and to overcome the shortage of rising feed. This study was carried out for three years between 2012 and 2015 to determine the yield and quality aspects of triticale genotypes in Yozgat ecological conditions. Experiments were carried out in randomized complete block design with four replications. As a result of the variance analysis, year, genotype and year $\times$ genotype interactions were found to be significant in terms of all traits examined. According to the results including years averages; plant height, the number of spikes per square meter, harvest index, grain yield, thousand grain weight, hectoliter weight, crude protein content, crude fat content, starch content, ash content, acid detergent fiber (ADF), neutral detergent fiber (NDF) value, Zeleny sedimentation value, wet gluten, $\mathrm{K}, \mathrm{P}$ and $\mathrm{Mg}$ were found between 84.1$107.6 \mathrm{~cm}, 288.0-508.7$ no, 28.6-38.8 \%, 230.4- 366.1 kg da-1, 29.0-40.3 g, 66.7- 71.3\%, 12.3-14.8\%, $1.11-$ $1.76 \%, 62.2-66.2 \%, 1.68-2.17 \%, 2.437-3.585 \%, 17.5-19.1 \%, 20.3-30.9 \mathrm{ml}, 22.4-26.5 \%, 0.525-0.668 \%$, $0.129-0.150 \%$ and $0.366-0.408 \%$, respectively. The highest grain yield was obtained from numbered 14 (351.7 $\mathrm{kg}$ da-1), 15 (359.7 kg da-1), 23 (340.2 kg da-1) and 24 (366.1 kg da-1) triticale genotypes. Positive and significant correlation was found for plant height $(\mathrm{r}=0.422 * *)$, number of spikes per square meter $\left(\mathrm{r}=0.405^{* *}\right)$, harvest index $\left(\mathrm{r}=0.548^{* *}\right), 1000$-grain weight $\left(\mathrm{r}=0.479^{* *}\right)$, hectoliter weight $\left(\mathrm{r}=0.559^{* *}\right)$ and $\mathrm{P}\left(\mathrm{r}=0.129^{*}\right)$ with grain yield. protein content $\left(\mathrm{r}=-0.238^{* *}\right)$, crude fat content $\left(\mathrm{r}=-0.126^{*}\right)$, ADF $\left(\mathrm{r}=-0.119^{*}\right)$, NDF $(\mathrm{r}=$ $\left.0.566^{* *}\right)$, Zeleny sedimentation value $\left(\mathrm{r}=-0.304^{* *}\right)$ and wet gluten $\left(\mathrm{r}=-0.496^{* *}\right)$ showed negative correlation with grain yield. According to the Biplot analysis graph, the 23 numbered genotype with high grain yield also appeared to be in the foreground in terms of properties such as plant height, 1000-grain weight, Zeleny sedimentation value, wet gluten, protein content, $\mathrm{K}, \mathrm{P}$ and $\mathrm{Mg}$. For grain yield, genotype 7 had good adaptation

Anahtar Sözcükler: Tritikale Verim Kalite Korelasyon Stabilite

Keywords: Triticale Yield Quality Correlation Stability

C OMU ANAJAS 2018 
to all environments, genotypes 3, 4, 9 and 21 had moderate adaptation to good environments.

\section{Giriş}

Hızla artan dünya nüfusunun yeterli ve dengeli beslenebilmesi için gıda üretiminin de hızla artırılması gerekmektedir. $\mathrm{Bu}$ da yeni yetiştirme tekniklerinin geliştirilmesi ve uygulanması yanında daha verimli ve kaliteli bitki çeşitlerinin geliştirilmesi ile mümkündür. Buğday ile çavdarın melezi olan ve nispeten yeni bir tahıl cinsi olan Tritikale ( $\times$ Triticosecale Wittmack) biyotik ve abiyotik stres koşullarına buğdaydan daha toleranslıdır. Bundan dolayı da marjinal alanlar için daha uygun bir bitkidir (Villegas ve ark., 2010). Diğer tahıllarla kıyaslandığında tritikale yüksek verim yanında, geniş adaptasyon yeteneği ve yüksek besin içeriğine sahiptir (Oettler, 2005). Ayrıca buğdaya göre yabanc1 otlarla rekabet gücüde daha yüksektir (Beres ve ark., 2010). Özellikle, buğday tarımına uygun olmayan toprak derinliği az, çorak ve kışları çok sert geçen bölgelerin değerlendirilmesinde ve artan yem açı̆̆ının kapatılmasında tritikale önemli bir alternatif bitki olarak karşımıza çıkmaktadır. Dünya tritikale üretimi son 15 yılda \% 40'ın üzerinde artış göstermiştir. Son yıllara kadar ağırlıklı olarak tanesi ve otu hayvan yemi olarak kullanılan tritikale son yıllarda insan yiyeceği ve etanol üretiminde de kullanılmaya başlanmıştır. Dünyada 3.8 milyon ha ekim alanı ve 14.7 milyon ton üretime sahip olan tritikale'nin en fazla tarımının yapıldığı ülkeler; Polonya, Almanya, Avustralya, Çin ve Fransa'dır (FAO, 2014). Ülkemizde ise tritikale üretimi ile ilgili istatiksel veriler 2004 yılından sonra verilmeye başlanmış olup, 2016 yilında 37.2 bin ha alanda ekilmiş ve bu alandan yaklaşık 125 bin ton tane ürünü elde edilmiştir. Tritikale dekara yaklaşı $336 \mathrm{~kg}$ ile ülkemizde tarımı yapılan serin iklim tahılları içinde verimi en yüksek türdür (TÜİK, 2016).

Çizelge 1. Çalışmada yer alan genotiplerin pedigrileri

\begin{tabular}{|c|c|c|c|}
\hline No & Melez / Pedigri & No & Melez / Pedigri \\
\hline 1 & MELEZ 2001 / 01-02 STBVD-21 & 13 & $\begin{array}{l}\text { CIMMYT-1/4/RUUNA-3-2/GIBON-3/3/ARDI- } \\
\text { 1/TOPO1419//... }\end{array}$ \\
\hline 2 & MİKHAM-2002 / 01-02 STBVD-21 & 14 & CIMMYT-1/TATLICAK-97 \\
\hline 3 & MİKHAM-2002 / JUANİLLO & 15 & CIMMYT-2/TATLICAK-97 \\
\hline 4 & CIMMYT-3 / ANOAS_3/TATU_4//SUSI_2 & 16 & ARDI_1/TOPO1419//ERIZO_9/3/2*KETTU_1/4/RU \\
\hline 5 & CIMMYT-3 / 01-02 KTVD-32 & 17 & NE 861 665/SUSI-2//TATLICAK-97 \\
\hline 6 & 01-02 KTBVD-1/23FAHAT5/POLLMER3 & 18 & ANOAS-3/GNU-14-1//KARMA \\
\hline 7 & 01-02 KTBVD-1/JUANILLO & 19 & $\begin{array}{l}\text { ARDI_1/TOPO1419//ERIZO_9/3/2*KETTU_1/4/LT } \\
\text { 472.82/MUSMON-1 }\end{array}$ \\
\hline 8 & 01-02 KTBVD-24/ ANOAS_3/TATU_4//SUSI_2 & 20 & PRESTO (Standart) \\
\hline 9 & 01-02 KTVD-25/KARMA & 21 & $\begin{array}{l}\text { 6TB219/3/6TA876//6TB163/6TB164/4/2*.../5/RUU } \\
\text { NA-3-2/GIBON-3/3/ARDI-1/TOPO1419//... }\end{array}$ \\
\hline 10 & KARMA2000 (Standart) & 22 & FAHAD_5/LT472.82/MUSMON-1 \\
\hline 11 & $\begin{array}{l}\text { 20ERIZO8/RHINO3/NIMIR3/5MAH484CRNYVTS } \\
\text { S/POLLMER_3/FOCA_2-1 }\end{array}$ & 23 & $\begin{array}{l}\text { TATLICAK- } \\
\text { 97/LT451.75/M76.1/3/MUSX/LYNX//STIER-12-3 }\end{array}$ \\
\hline 12 & CT776.81//PĀSSI_4-1/N̄IMIR_3/01-02 KTVD-24 & 24 & BDMT 06-5K \\
\hline
\end{tabular}

Son yıllarda sağlanan gelişmeler ile tritikale insan gıdalarının üretiminde tek başına kullanılabildiği gibi özellikle kaliteli buğday unu ile değişik oranlarda karıştırılarak pasta, bisküvi, ekmek ve makarna yapımında kullanılabilmektedir. Düşük gluten miktarı ve kalitesi, yüksek miktardaki alfa amilaz aktivitesi tritikalenin ekmeklik kalitesini düşürmektedir. Ayrıca, ülkemizde oldukça yüksek oranda olan kaba ve kesif yem açı̆̆ının kapatılmasında kulla $\neg$ nılabilecek önemli bitkilerden birisidir.

Tanesinin yem değeri arpa ve çavdardan daha iyi buğdaya ise eşit durumda (Çifçi ve ark., 2010) olan tiritikalenin tane verimi yüksek ve kaliteli genotiplerinin belirlenmesi üretim potansiyelini artıracaktır. $\mathrm{Bu}$ çalışma, Yozgat koşullarında farklı orijinlere sahip tritikale genotiplerinin tane verimi ve bazı kalite özelliklerinin belirlenmesi ve üstün özelliklere sahip olan hatların tespit edilmesi amacıyla yürütülmüştür.

\section{Materyal ve Yöntem}

$\mathrm{Bu}$ çalışma, Yozgat ili Yerköy ilçesinde bulunan Bozok Üniversitesi Tarımsal Uygulama ve Araştırma Merkezine ait deneme alanında 3 yıl süreyle yürütülmüş̧ür. Araştırmada bitki materyali olarak 22 tritikale hattı ve 2 tritikale çeşidi kullanılmıştır (Çizelge 1). Deneme tesadüf blokları deneme desenine göre 4 tekerrürlü olarak 2012-2015 yılları arasında 
yürütülmüştür. Ekimler parsel ekim mibzeri ile $6 \mathrm{~m}$ uzunluğundaki parsellere $20 \mathrm{~cm}$ sıra arası mesafe olacak şekilde 8 sıra olarak kurulmuştur. Ekim işlemi her üç yılda da ekim ayının ilk haftasında, $\mathrm{m}^{2}$, ye yaklaşık 550 tohum düşecek şekilde yapılmıştır. Dekara $8 \mathrm{~kg}$ saf N hesabıyla gübre kullanılmış ve azotun yarısı ekimle diğer yarısı ise sapa kalkma dönemi öncesinde verilmiştir. Dekara $6 \mathrm{~kg} \mathrm{P}_{2} \mathrm{O}_{5}$ ekimden önce taban gübresi Diamanyum fosfat (DAP) olarak verilmiştir (Ünver, 1999). Yabancı otları kontrol etmek için herbisit kullanılmıştır.

Hasat işlemi; parsel kenarlarından birer sıra ve parsel başlarından 50 'şer $\mathrm{cm}$ kenar tesir atıldıktan sonra geriye kalan kısım orakla biçilmiştir. Hasattan sonra bitkiler 23 gün kurutulmuş, toplam ağırlıkları alınmış ve harman makinesi ile harmanlanmıştır.Araştırmada bitki boyu
(BB), metrekaredeki başak sayısı (MBS), bin tane ağırlığı (BTA), hektolitre ağırlığı (HA), tane verimi (TV), hasat indeksi (HI), protein oranı (PO), yağ oranı (YO), nişasta oranı (NO), kül oranı (KO), asit deterjanda çözünmeyen lif (ADF) değeri, nötr deterjanda çözünmeyen lif (NDF) değeri, Zeleny sedimantasyon değeri (ZSD), yaş gluten değeri (YG), potasyom $(\mathrm{K})$, magnezyum $(\mathrm{Mg})$ ve fosfor $(\mathrm{P})$ içerikleri incelenmiştir.BB ve MBS verilerinin elde edilmesi Yanbeyi ve Sezer (2006), HA, BTA, PO, YO, KO, SD, YG ölçüm ve analizleri Elgün ve ark. (2001)'na göre yapılmıştır. ADF ve NDF değerleri Van Soest ve ark. (1991)'na göre, NO ise Ewers Polarimetrik metoda (AACC, 2005) göre belirlenmiştir.

Çizelge 2. Yozgat İline ait 2012-2015 yılları arası ve uzun yıllar ortalaması iklim verileri*

\begin{tabular}{|c|c|c|c|c|c|c|c|c|c|c|c|}
\hline & Ekim & Kasım & Aralık & Ocak & Şubat & Mart & Nisan & May1s & Haziran & Temmuz & Ort/Top. \\
\hline \multicolumn{12}{|c|}{ Toplam Yağış (mm) } \\
\hline $2012-2013$ & 53.7 & 55.9 & 120.3 & 75.4 & 78.5 & 54.2 & 35.9 & 22.0 & 35.6 & 3.7 & 535.2 \\
\hline $2013-2014$ & 22.1 & 36.5 & 25.1 & 58.7 & 17.6 & 116.7 & 31.6 & 121.8 & 79.8 & 3.7 & 513.6 \\
\hline $2014-2015$ & 72.6 & 61.3 & 53.3 & 54.5 & 68.0 & 115.3 & 28.0 & 131.6 & 95.3 & 7.1 & 687.0 \\
\hline Uzun Yillar & 42.6 & 63.8 & 76.6 & 65.1 & 61.5 & 62.1 & 69.5 & 62.1 & 42.2 & 14.8 & 560.3 \\
\hline \multicolumn{12}{|c|}{ Ortalama Sicaklık $\left({ }^{\circ} \mathrm{C}\right)$} \\
\hline $2012-2013$ & 12.8 & 6.1 & 2.1 & 0.1 & 3.0 & 5.3 & 9.9 & 16.3 & 18.2 & 19.2 & 9.3 \\
\hline $2013-2014$ & 8.6 & 5.5 & -3.0 & 1.3 & 2.7 & 5.2 & 10.8 & 13.6 & 16.8 & 21.8 & 8.3 \\
\hline $2014-2015$ & 10.6 & 4.2 & 4.1 & -1.0 & 0.8 & 4.4 & 6.1 & 14.1 & 16.0 & 19.8 & 7.9 \\
\hline Uzun Yillar & 10.2 & 4.2 & 0.0 & -2.0 & -0.9 & 3.0 & 8.3 & 12.9 & 16.8 & 19.8 & 9.0 \\
\hline \multicolumn{12}{|c|}{ Ortalama Nem $(\%)$} \\
\hline $2012-2013$ & 61.7 & 79.8 & 81.2 & 77.6 & 72.4 & 63.8 & 61.3 & 47.8 & 46.1 & 46.6 & 63.8 \\
\hline $2013-2014$ & 55.4 & 67.2 & 71.0 & 75.5 & 61.9 & 63.5 & 53.4 & 60.4 & 56.0 & 43.2 & 60.7 \\
\hline $2014-2015$ & 69.3 & 70.2 & 77.9 & 76.7 & 73.3 & 69.5 & 61.9 & 59.9 & 71.5 & 54.7 & 68.4 \\
\hline Uzun Yillar & 65.9 & 72.1 & 76.8 & 77.0 & 74.9 & 70.0 & 66.6 & 64.0 & 60.3 & 56.6 & 68.4 \\
\hline
\end{tabular}

*İklim verileri Yozgat Meteoroloji Müdürlüğünden alınmıştır.

Deneme alanının toprak bünyesi killi-tın (\% 54.78) bir yapıya sahiptir. Tuzsuz (\% 0.018) olan deneme toprakları, alkali karakterde ( $\mathrm{pH}: 8.20)$, fosfor $(8.62 \mathrm{~kg}$ $\left.\mathrm{da}^{-1}\right)$ ve kireç içeriği $(\% 7.93)$ orta seviyede, potasyum bakımından zengin $\left(48.47 \mathrm{~kg} \mathrm{da}^{-1}\right)$ ve organik madde (\% 1.91) bakımından fakirdir. Denemenin yürütüldüğ̈̈ yere ait yağış, sıcaklık ve nispi nem değerlerine ait veriler Çizelge 2'de verilmiștir. Çizelge 2'de görüldüğü üzere, denemenin yürütüldüğ̈̈ yerdeki vejetasyon süresince uzun yıllar yağış toplamı $(560.3 \mathrm{~mm})$, denemenin birinci $(535.2 \mathrm{~mm})$ ve ikinci $(513.6 \mathrm{~mm})$ y1l yağ 1 ș toplamından yüksek, üçüncü $(687.0 \mathrm{~mm})$ yıldan düşük gerçekleşmiştir. Vejetasyon döneminde, uzun yıllar sicaklık ortalamas $9.0{ }^{\circ} \mathrm{C}$ olmuş, bu değer denemenin birinci yllından düşük $\left(9.3{ }^{\circ} \mathrm{C}\right)$ olurken, ikinci $\left(8.3^{\circ} \mathrm{C}\right)$ ve üçüncü $\left(7.9^{\circ} \mathrm{C}\right)$ yılından yüksek olmuştur (Tablo 2). Uzun y1llara ait ortalama nispi nem \% 68.4 iken, deneme yıllarına ait nispi nem değerleri sırası ile \% 63.8, 60.7 ve 68.4 olarak gerçekleşmiştir (Çizelge 2)Araştırmada elde edilen sonuçlar SAS istatistik analiz programında yapılmıs (SAS, 1998), farklılık belirlenen özelliklerin ortalamaları arasındaki karşılaştırmalar ise
Duncan çoklu karşıllaştırma testi ile değerlendirilmiştir. Biplot analizi, Biplot Makro eklentisi (Lipkovich ve Smith, 2002) ile Microsoft Excel programında yapılmıştır. Genotip x yıl kombinasyonu bir çevre olarak kabul edilmiş ve bu interaksiyon önemli çıkması üzerine Finlay ve Wilkinson (1963)'ın önerdiği regresyon katsayısı (bi) ve ortalama verim üzerinden genotiplerin adaptasyon durumları belirlenmiştir.

\section{Bulgular ve Tartış̧a}

Yozgat şartlarında 3 yıl süresince yetiştirilen 24 tritikale genotipinin verim ve bazı kalite özelliklerinin belirlenmesi amacıyla yürütülen bu çalışmada varyans analizi sonuçlarına göre incelenen tüm özellikler için genotip, yll ve genotip $\mathrm{x}$ y1 interaksiyonu $\mathrm{P} \leq 0.01$ seviyesinde önemli bulunmuştur. Denemeye alınan genotiplerin incelenen özelliklerine ilişkin ortalama değerler Çizelge 3, 4 ve 5'de verilmiştir.

Üç yılın ortalamasına göre bitki boyu (BB) 84.1 (19 numaralı hat) ile $107.6 \mathrm{~cm}$ (23 numaralı hat) arasinda değişmiş ve ortalama BB $96.0 \mathrm{~cm}$ olmuştur. İstatistiki 
olarak aynı grupta yer alan 16 ve 23 numaralı genotipler BB bakımından diğer genotiplerden daha yüksek değer göstermişlerdir (Çizelge 3). Yılların ortalaması olarak 2012-2013, 2013-2014 ve 2014-2015 yetiştirme sezonlarında sırasıyla bitki boyu $84.1,99.9$ ve $104.0 \mathrm{~cm}$ olarak tespit edilmiştir. Bitki boyunun yıllara göre farklı olması iklim koşullarından özelliklede düşen yağışın farklı olmasından kaynaklanmış olabilir. Ayrıca, genotip $\times$ y1l interaksiyonunun önemli olması, değişen iklim ve çevre koşullarına genotiplerin farklı yanıtlar verebileceğini göstermektedir (Çizelge 2). Tahıllarda verim, verim unsurları ve kalite özellikleri yanında bitki boyu da üzerinde en fazla durulan morfolojik özelliklerden birisidir. Tritikale sadece tane amaçlı değil, marjinal koşullarda hayvan beslemede büyük oranda kullanilan sap, saman, hasil yem ve ot silaj1 şeklinde kaba yem olarak da tüketilebilen bir tahıl olduğundan bitki boyu önemlidir (Kutlu ve Kınacı, 2011).Yapılan araştırmalarda tritikalede bitki boyunun genotiplere göre farklılıklar gösterdiği bildirilmiştir (Atak ve Çiftçi, 2006; Mut ve ark., 2006; Akgün ve ark., 2007; Geren ve ark., 2012; Tayyar ve Kahrıman, 2016).

Yılların ortalamasına göre genotiplerin metrekaredeki başak sayısı (MBS) 288.0 (1 numaralı hat) ile 508.7 adet (22 numaralı hat) arasında değişmiş ve ortalama MBS 409.9 adet olmuştur. 7, 15, 16, 17, 21, 22 ve 23 numaralı genotipler en yüksek MBS'ye sahip olmuşlar ve istitistiki olarak aynı grupta yer almışlardır (Çizelge 3). Çalışmanın birinci, ikinci ve üçüncü yıllarında metrekaredeki başak sayısı sırasıyla 382.2, 415.7 ve 431.8 adet olarak tespit edilmiştir. Genotiplerin MBS değerleri yıllara göre de büyük farklılıklar göstermiştir.

Çizelge 3. Tritikale genotiplerinin BB, MBS, HI, TV, BTA ve HA'na ait ortalama değerler*

\begin{tabular}{|c|c|c|c|c|c|c|c|c|c|c|c|c|}
\hline Ceșitler & \multicolumn{2}{|c|}{ BB } & \multicolumn{2}{|c|}{ MBS } & \multicolumn{2}{|c|}{$\mathrm{HI}$} & \multicolumn{2}{|c|}{ TV } & \multicolumn{2}{|c|}{ BTA } & \multicolumn{2}{|c|}{ HA } \\
\hline 1 & 98.1 & bcd & 288.0 & $\mathrm{k}$ & 35.6 & $\mathrm{~cd}$ & 254.4 & $\operatorname{lmn}$ & 35.9 & gh1 & 68.7 & hij \\
\hline 2 & 96.5 & $c-f$ & 373.0 & g-i & 33.0 & ef & 276.1 & $\mathrm{kl}$ & 29.0 & $\mathrm{n}$ & 68.6 & hij \\
\hline 3 & 97.4 & $b-e$ & 385.0 & $f-j$ & 37.5 & $a b$ & 296.4 & g-k & 35.7 & h1 & 68.4 & ij \\
\hline 4 & 98.8 & bcd & 434.7 & $c-f$ & 37.0 & $a b c$ & 317.2 & d-h & 34.5 & $1 \mathrm{jk}$ & 68.1 & $\mathrm{jk}$ \\
\hline 5 & 99.9 & bcd & 370.1 & g-j & 31.7 & fgh & 271.8 & $\mathrm{klm}$ & 37.6 & def & 68.4 & $1 \mathrm{j}$ \\
\hline 6 & 96.2 & $c-f$ & 415.9 & d-h & 30.8 & gh & 291.3 & h-k & 36.4 & f-g & 70.6 & $a-d$ \\
\hline 7 & 90.3 & h1 & 454.0 & $a-e$ & 36.1 & bcd & 333.7 & b-f & 31.5 & $\mathrm{~m}$ & 66.7 & 1 \\
\hline 8 & 100.2 & bcd & 433.7 & $c-f$ & 35.8 & bcd & 328.2 & $c-f$ & 32.6 & $\operatorname{lm}$ & 71.3 & $\mathrm{a}$ \\
\hline 9 & 95.1 & d-h & 334.3 & $\mathrm{jk}$ & 28.7 & 1 & 286.7 & $\mathrm{j} 1 \mathrm{k}$ & 35.7 & hij & 69.7 & efg \\
\hline 10 & 89.2 & $1 \mathrm{j}$ & 395.4 & $\mathrm{e}-1$ & 35.5 & $\mathrm{~cd}$ & 335.2 & b-e & 34.3 & $\mathrm{jk}$ & 69.8 & $c-f$ \\
\hline 11 & 92.4 & $e-1$ & 360.2 & hij & 28.6 & 1 & 243.4 & $\mathrm{mn}$ & 37.4 & def & 68.2 & $\mathrm{jk}$ \\
\hline 12 & 95.7 & $\mathrm{c}-\mathrm{g}$ & 341.6 & $1 \mathrm{jk}$ & 30.1 & $h_{1}$ & 276.6 & $\mathrm{jkl}$ & 39.4 & $a b c$ & 67.2 & 1 \\
\hline 13 & 90.8 & gh1 & 447.4 & b-e & 32.6 & fg & 327.8 & $c-f$ & 36.8 & e-h & 70.4 & b-e \\
\hline 14 & 98.4 & bcd & 425.3 & c-g & 38.7 & a & 351.7 & $a b c$ & 38.7 & bcd & 70.7 & $a b c$ \\
\hline 15 & 101.0 & $\mathrm{bc}$ & 477.1 & $a b c$ & 38.9 & $\mathrm{a}$ & 359.7 & $a b$ & 37.1 & $e-h$ & 69.8 & d-g \\
\hline 16 & 102.2 & $a b$ & 479.1 & $a b c$ & 34.9 & de & 325.7 & $\mathrm{c}-\mathrm{g}$ & 37.3 & efg & 70.0 & $b-f$ \\
\hline 17 & 99.6 & bcd & 494.3 & $a b$ & 35.5 & $\mathrm{~cd}$ & 349.8 & $\mathrm{abc}$ & 38.0 & cde & 69.2 & $f-1$ \\
\hline 18 & 95.3 & d-h & 344.1 & $1 \mathrm{jk}$ & 30.1 & $h_{1}$ & 282.5 & $\mathrm{j}-1$ & 40.3 & $\mathrm{a}$ & 67.5 & $\mathrm{kl}$ \\
\hline 19 & 84.1 & $\mathrm{j}$ & 340.9 & $1 \mathrm{jk}$ & 28.6 & 1 & 230.4 & $\mathrm{n}$ & 40.0 & $a b$ & 68.2 & $\mathrm{jk}$ \\
\hline 20 & 89.1 & $1 \mathrm{ij}$ & 350.9 & $1 \mathrm{ij}$ & 28.8 & 1 & 280.9 & $\mathrm{j}-1$ & 33.9 & $\mathrm{kl}$ & 69.3 & fgh \\
\hline 21 & 97.4 & b-e & 466.0 & $a-d$ & 31.9 & fgh & 305.7 & $f-j$ & 36.2 & f-e & 69.2 & $f-1$ \\
\hline 22 & 91.2 & $f-1$ & 475.8 & $a b c$ & 35.6 & $\mathrm{~cd}$ & 307.2 & $\mathrm{e}-1$ & 39.5 & $a b$ & 68.9 & g-j \\
\hline 23 & 107.6 & $\mathrm{a}$ & 508.7 & $\mathrm{a}$ & 33.0 & ef & 340.2 & $a-d$ & 38.1 & cde & 69.8 & $c-f$ \\
\hline 24 & 97.2 & b-e & 441.7 & b-f & 35.4 & $\mathrm{~cd}$ & 366.1 & $\mathrm{a}$ & 33.4 & $\mathrm{kl}$ & 70.7 & $a b$ \\
\hline $2012-13$ & 84.1 & $\mathrm{C}$ & 382.2 & B & 34.0 & B & 256.2 & $\mathrm{~B}$ & 35.6 & B & 68.9 & $\mathrm{~B}$ \\
\hline 2013-14 & 99.9 & B & 415.7 & A & 30.6 & $\mathrm{C}$ & 238.3 & $\mathrm{C}$ & 33.4 & $\mathrm{C}$ & 67.6 & $\mathrm{C}$ \\
\hline $2014-15$ & 104.0 & A & 431.8 & A & 35.9 & A & 422.8 & A & 39.7 & A & 70.9 & A \\
\hline Ortalama & \multirow{2}{*}{\multicolumn{2}{|c|}{96.0}} & \multirow{2}{*}{\multicolumn{2}{|c|}{$\begin{array}{r}409.9 \\
18.9\end{array}$}} & \multirow{2}{*}{\multicolumn{2}{|c|}{34.4}} & \multirow{2}{*}{\multicolumn{2}{|c|}{$\begin{array}{r}305.8 \\
110\end{array}$}} & \multirow{2}{*}{\multicolumn{2}{|c|}{36.2}} & \multicolumn{2}{|c|}{69.1} \\
\hline VK & & & & & & & & & & & & \\
\hline
\end{tabular}

Söz konusu bu değişim genotip $\times$ yıl interaksiyonunu önemli çıkarmıştır. Tahıllarda belirli bir sıklığa kadar tane verimi olumlu yönde etkilenirken, belirli bir sıklıktan sonra azalmaktadır. Genotiplerin kardeşlenme güçlerinin farklı olması da bitki sıklığını etkilemektedir (Yanbeyi ve Sezer, 2006).

Üç yılın ortalamasına göre genotiplerin tane verimi 230.4 (19 numaralı hat) ile $366.1 \mathrm{~kg} \mathrm{da}^{-1}$ (24 numaralı hat) arasında değişmiş ve ortalama tane verimi $305.8 \mathrm{~kg}$ $\mathrm{da}^{-1}$ olmuştur. Çalışmada 14, 15, 17, 23 ve 24 numaralı genotipler en yüksek tane verimine sahip olmuş ve istatitistiki olarak aynı grupta yer almışlardır. Büyük oranda genetik yapıya bağlı olan tane verimi, çevresel faktörlerden de önemli düzeylerde etkilenmektedir. Tane verimi birinci, ikinci ve üçüncü yıl sırasıyla 256.2, 238.3 ve $422.8 \mathrm{~kg} \mathrm{da}^{-1}$ olarak tespit edilmiştir (Çizelge $3)$. Tane verimi bakımından önemli olduğu belirlenen genotip $\times$ y1l interaksiyonu genotiplerin verim performanslarının yıllara göre değiştiğini göstermiştir. Söz konusu interaksiyon, iklim koşullarının nispeten daha iyi olduğu üçüncü deneme yllında genotipler arasında belirgin farklılıkların olduğu görülmüştür. Tane 
veriminde genotip x yıl interaksiyonunun önemi bazı araştırmacılar tarafindan da vurgulanmıştır (Mut ve ark., 2006; Akgün ve ark., 2007; Akgün ve Altındal, 2011). $\mathrm{m} 2$ 'de başak sayısı, başakta tane sayısı ve tane ağırlığının tane verimini etkileyen en önemli öğeler olduğu bildirilmiştir (Akgün ve ark., 1997). Yapılan çalıșmalarda tane verimi $336.00-623.73 \mathrm{~kg} \mathrm{da}^{-1}$ (Albayrak ve ark., 2006), 358.8 - $564.4 \mathrm{~kg} \mathrm{da}^{-1}$ (Mut ve ark., 2006), $229.5-357.1 \mathrm{~kg} \mathrm{da}^{-1}$ (Akgün ve ark., 2007), $378.18-478.30 \mathrm{~kg} \mathrm{da}^{-1}$ (Alp, 2009), $157-539 \mathrm{~kg} \mathrm{da}^{-1}$ (Geren ve ark., 2012), 367.1-277.9 $\mathrm{kg} \mathrm{da}^{-1}$ (Tayyar ve Kahrıman, 2016) 537.5-678.5 kg da ${ }^{-1}$ (Kızılgeçi ve Yıldırım, 2017) ve 395.6 ile $779.3 \mathrm{~kg} \mathrm{da}^{-1}$ (Kızılgeçi ve ark., 2017) arasında değiştiği bildirilmiştir.

Yılların ortalamasına göre çeşitlerin bin tane ağırlığ (BTA) 29.0 (2 numaralı hat) ile $40.3 \mathrm{~g}$ (18 numaralı hat) arasında değişmiş ve ortalama BTA $36.2 \mathrm{~g}$ olmuştur. BTA ağırlığı bakımında $12,18,19$ ve 22 numaralı genotipler en yüksek değere sahip olmuş ve istatistiki olarak aynı grupta yer almışlardır. BTA 2012-2013, 2013-2014 ve 2014-2015 yetiştirme sezonlarında sirasıyla 35.6, 33.4 ve $39.7 \mathrm{~g}$ olarak tespit edilmiştir (Çizelge 3). Genotip $\times$ y1l interaksiyonunun önemli olması, değişen iklim ve çevre koşullarına genotiplerin farklı tepkiler verdiğini göstermektedir. Pek çok araştırıcı (Yanbeyi ve Sezer, 2006; Mut ve ark., 2006; Kızılgeçi ve Yıldırım, 2017) tritikale genotipleri arasında bin tane ağırlığı bakımından önemli farkların bulunduğunu bildirmişlerdir. Albayrak ve ark. (2006) Samsun koşullarında yaptıkları bir çalışmada, bin tane ağırlığının 33.00-47.18 g; Çif̧̧i ve ark. (2010) Bursa koşullarında 43.3-55.7 g ve Kendal ve Sayar (2016) Güneydoğu Anadolu şartlarında 32.9-49.3 g arasında olduğunu bildirmişlerdir.

Üç yılın ortalamasına göre hektolitre ağırlığı (HA) 66.7 (7 numaralı hat) ile $71.3 \mathrm{~kg}$ (8 numaralı hat) arasında değişmiştir. $6,8,14$ ve 24 numaralı genotipler en yüksek HA'ya sahip olurken, 7, 12 ve 18 numaralı genotipler en düşük HA'ya sahip olmuştur. Birinci, ikinci ve üçüncü yıl HA sırasıyla $68.9,67.6,70.9 \mathrm{~kg}$ olmuştur (Çizelge 3).

Kalitenin belirlenmesinde kullanılan en kolay ve önemli özelliklerden birisi olarak kabul edilen hektolitre ağırlığı ürünün ticari değerinin belirlenmesinde önem taşımaktadır.

Çizelge 4. Tritikale genotiplerinin PO, YO, NO, KO, ADF ve NDF'ye ait ortalama değerler*

\begin{tabular}{|c|c|c|c|c|c|c|c|c|c|c|c|c|}
\hline Çeşitler & \multicolumn{2}{|c|}{$\mathrm{PO}$} & \multicolumn{2}{|c|}{$\mathrm{YO}$} & \multicolumn{2}{|c|}{$\mathrm{NO}$} & \multicolumn{2}{|c|}{$\mathrm{KO}$} & \multicolumn{2}{|c|}{ ADF } & \multicolumn{2}{|c|}{ NDF } \\
\hline 1 & 13.8 & $\mathrm{~b}$ & 1.53 & $\mathrm{~cd}$ & 62.8 & fgh & 2.04 & bcd & 2.77 & ef & 18.2 & h-k \\
\hline 2 & 13.7 & bcd & 1.58 & $\mathrm{bc}$ & 62.4 & $\mathrm{~h}$ & 2.17 & $\mathrm{a}$ & 3.19 & $\mathrm{bc}$ & 18.9 & $a b c$ \\
\hline 3 & 13.8 & $\mathrm{bc}$ & 1.55 & $\mathrm{bc}$ & 63.1 & $f-g$ & 2.01 & $c-f$ & 3.32 & $\mathrm{~b}$ & 18.6 & $c-g$ \\
\hline 4 & 13.6 & c-e & 1.38 & fgh & 63.3 & $c-f$ & 2.06 & $\mathrm{bc}$ & 3.21 & $\mathrm{~b}$ & 18.8 & $a b c$ \\
\hline 5 & 13.7 & bcd & 1.57 & $\mathrm{bc}$ & 62.4 & $\mathrm{~h}$ & 2.04 & bcd & 3.25 & $\mathrm{~b}$ & 18.7 & $b-f$ \\
\hline 6 & 13.4 & $c-f$ & 1.11 & $\mathrm{j}$ & 63.8 & bcd & 2.02 & cde & 2.80 & ef & 18.5 & d-h \\
\hline 7 & 13.3 & $\mathrm{~d}-\mathrm{f}$ & 1.24 & 1 & 63.2 & $f-g$ & 2.10 & $a b c$ & 3.27 & $\mathrm{~b}$ & 19.1 & $\mathrm{a}$ \\
\hline 8 & 12.6 & $\mathrm{jk}$ & 1.45 & def & 66.4 & $\mathrm{a}$ & 1.68 & $\mathrm{k}$ & 3.08 & bcd & 17.7 & $1 \mathrm{~m}$ \\
\hline 9 & 13.5 & $c-f$ & 1.58 & $\mathrm{bc}$ & 62.5 & fgh & 2.05 & bcd & 3.33 & $a b$ & 18.9 & $a b$ \\
\hline 10 & 13.0 & g-1 & 1.39 & fgh & 63.8 & bcd & 1.91 & $f-1$ & 3.28 & $\mathrm{~b}$ & 18.5 & d-h \\
\hline 11 & 13.0 & g-1 & 1.52 & $\mathrm{~cd}$ & 63.2 & def & 1.90 & h1 & 3.26 & $\mathrm{~b}$ & 18.4 & $f-j$ \\
\hline 12 & 13.7 & bcd & 1.42 & fgh & 62.2 & $\mathrm{~h}$ & 2.14 & $a b$ & 2.77 & ef & 18.6 & $b-f$ \\
\hline 13 & 13.5 & $c-f$ & 1.21 & 1 & 62.5 & gh & 2.06 & $\mathrm{bc}$ & 2.51 & g & 18.1 & $\mathrm{k}$ \\
\hline 14 & 13.0 & g-1 & 1.22 & 1 & 64.3 & b & 1.91 & e-1 & 2.84 & def & 18.3 & g-k \\
\hline 15 & 12.8 & hij & 1.63 & $\mathrm{~b}$ & 64.3 & $\mathrm{~b}$ & 1.85 & hij & 3.23 & $\mathrm{~b}$ & 18.0 & $\mathrm{kl}$ \\
\hline 16 & 13.2 & $e-h$ & 1.39 & fgh & 64.3 & $\mathrm{~b}$ & 1.84 & $1 j$ & 2.44 & $\mathrm{~g}$ & 17.5 & $\mathrm{~m}$ \\
\hline 17 & 12.7 & $1 \mathrm{jk}$ & 1.34 & $\mathrm{~h}$ & 63.7 & bcd & 1.86 & hij & 3.21 & $\mathrm{~b}$ & 18.3 & g-k \\
\hline 18 & 13.1 & $\mathrm{f}-1$ & 1.35 & gh & 62.6 & fgh & 2.01 & $c-f$ & 2.94 & cde & 18.6 & b-g \\
\hline 19 & 13.6 & $c-e$ & 1.38 & fgh & 62.8 & fgh & 1.94 & $d-1$ & 3.10 & $\mathrm{bc}$ & 18.8 & bcd \\
\hline 20 & 13.2 & e-h & 1.51 & cde & 63.5 & cde & 2.00 & $c-g$ & 3.16 & $\mathrm{bc}$ & 18.7 & $b-e$ \\
\hline 21 & 13.4 & $c-f$ & 1.43 & efg & 63.7 & bcd & 1.92 & e-1 & 2.59 & fg & 18.1 & $1 \mathrm{jk}$ \\
\hline 22 & 13.0 & gh1 & 1.50 & cde & 64.0 & $\mathrm{cb}$ & 1.84 & $1 \mathrm{j}$ & 2.66 & fg & 18.1 & $\mathrm{jk}$ \\
\hline 23 & 14.8 & $\mathrm{a}$ & 1.40 & fgh & 62.9 & $e-h$ & 1.95 & d-h & 2.68 & $\mathrm{fg}$ & 18.8 & $a b c$ \\
\hline 24 & 12.3 & $\mathrm{k}$ & 1.76 & $\mathrm{a}$ & 64.3 & $\mathrm{~b}$ & 1.77 & $\mathrm{jk}$ & 3.59 & $\mathrm{a}$ & 18.4 & $e-1$ \\
\hline $2012-13$ & 13.4 & $\mathrm{~A}$ & 1.71 & A & 65.3 & A & 1.80 & $\mathrm{C}$ & 3.64 & $\mathrm{~A}$ & 18.3 & B \\
\hline 2013-14 & 13.5 & A & 1.23 & $\mathrm{C}$ & 61.7 & $\mathrm{C}$ & 2.07 & A & 2.56 & $\mathrm{C}$ & 19.3 & A \\
\hline 2014-15 & 13.0 & $\mathrm{~B}$ & 1.35 & $\mathrm{~B}$ & 63.3 & $\mathrm{~B}$ & 2.01 & $\mathrm{~B}$ & 2.86 & $\mathrm{~B}$ & 17.7 & $\mathrm{C}$ \\
\hline Ortalama & 13 & & 1. & & 63 & & 2. & & 3.1 & & & \\
\hline VK & 4. & & 7. & & 1. & & 6 & & 10 & & & \\
\hline
\end{tabular}

* PO: Protein oranı (\%); YO: Yağ oranı (\%), NO: Nişasta oranı (\%); KO: kül oranı (\%); ADF: Asit deterjanda çözünmeyen lif (\%); NDF: Nötr deterjanda çözünmeyen lif $(\%)$ 
Genotip $\times$ yıl interaksiyonunun önemli olmas1 denemede materyal olarak kullanilan genotiplerin değişen iklim koşullarına farklı tepkiler vermesinden kaynaklanabileceği düşünülmektedir. Yapılan çalışmalarda hektolitre ağılı ı̆ının $65.95-73.32 \mathrm{~kg}$ (Albayrak ve ark., 2006), $65.9-71.1 \mathrm{~kg}$ (Mut ve ark., 2006), 59.9 ile $76.9 \mathrm{~kg}$ (Akgün ve ark., 2007), 59.5-76.7 kg (Geren ve ark., 2012), 65.07- 83.65 kg (Kızılgeçi ve ark., 2017) arasında değiştiği bildirilmiştir.

Genotiplerin ortalama hasat indeksi (HI) \% 28.6 (19 numaralı hat) ile 38.8 (15 numaralı hat) arasinda değişmiş ve ortalama \% 33.5 olarak belirlenmiştir. Çalışmanın yürütüldüğü 2012-2013, 2013-2014 ve 2014-2015 yetiştirme sezonlarında HI sırasıyla \% 34.0, 30.6 ve 35.9 olarak tespit edilmiştir (Çizelge 3). Yapılan pek çok çalışmada hasat indeksinin \% 21.68 ile 31.51 (Ünver, 1999), \% 29.30 ile 36.37 (Atak, 2004), \% 29.3 ile 36.37 (Atak ve Çiftçi, 2006), \% 25.4 ile 31.6 (Akgün ve ark., 2007), \% 28.2 ile 44.2 (Kutlu ve Kınacı, 2011) arasında değiştiği bildirilmiştir.

Üç yılın ortalamasına göre genotiplerin protein oranı (PO) \% 12.3 (24 numaralı hat) ile 14.8 (23 numaralı hat) arasında değişmiş ve $1,2,3,4,5,6,7,9,12,13,19$ ve 23 numaralı genotipler genel ortalamanın (\% 13.3) üstünde PO'ya sahip olmuşlardır. Yılların ortalaması olarak 2012-2013, 2013-2014 ve 2014-2015 yetiştirme sezonlarında protein oranı sirasiyla $\% 13.4,13.5$ ve 13.0 olmuştur. Üçüncü yıl tane veriminin ve bin tane ağırlı̆̆ının daha fazla olması oransal olarak tanedeki protein oranının azalmasına neden olmuştur (Çizelge 4). Diğer serin iklim tahıllarına göre tritikalede protein oranının daha yüksek olabileceğini bildirilmektedir (Kün, 1996). Yapılan çalışmalarda protein oranının Brand ve ark. (2003) \% 13.9 ile 15.4, Atak ve Çiftçi (2006) 11.3 ile 14.3, Akgün ve ark. (2007) \% 10.3 ile 12.7, Alp (2009) \% 10.6 ile 11.4, Rakha ve ark. (2013) $\% 13.0$ ile 14.9, Kızılgeçi ve ark. (2017) \% 13.5 ile 16.3, Kızılgeçi ve Yıldırım (2017) \% $14.0-16.2$ arasında değiştiğini bildirmişlerdir.

Üç yılın ortalamasına göre genotiplerin yağ oranı (YO) \% 1.11 (6 numaralı hat) ile 1.76 (24 numaralı hat) arasında değişmiş ve $1,2,3,5,8,9,11,15,21$ ve 24 numaralı genotipler genel ortalamanın (\% 1.43) üstünde YO'ya sahip olmuşlardır. Yılların ortalaması olarak 2012-2013, 2013-2014 ve 2014-2015 yetiştirme sezonlarında YO sirasiyla \% 1.71, 1.23, 1.35 olarak bulunmuştur. Yapılan çalışmalarda yağ oranını Brand ve ark. (2003) \% 2.1 ile 2.3 ve Rakha ve ark. (2013) \% 1.13 ile 1.17 arasında değiştiğini bildirmişlerdir.

Çizelge 5. Tritikale genotiplerinin ADF, NDF, SD, YG, K, Mg ve P içeriklerine ilişkin ortalama değerler*

\begin{tabular}{|c|c|c|c|c|c|c|c|c|c|c|}
\hline Çeşitler & \multicolumn{2}{|c|}{ ZSD } & \multicolumn{2}{|c|}{ YG } & \multicolumn{2}{|c|}{$\mathrm{K}$} & \multicolumn{2}{|c|}{$\mathrm{Mg}$} & \multicolumn{2}{|c|}{$\mathrm{P}$} \\
\hline 1 & 29.9 & $a b$ & 25.7 & $c-f$ & 0.598 & efg & 0.140 & e-h & 0.397 & b-f \\
\hline 2 & 28.2 & $c-f$ & 25.2 & fgh & 0.643 & $a b$ & 0.143 & $c-g$ & 0.404 & $a b c$ \\
\hline 3 & 26.2 & $g-j$ & 25.4 & e-h & 0.627 & $b-f$ & 0.145 & a-e & 0.403 & $a-d$ \\
\hline 4 & 24.8 & klm & 25.3 & $e-h$ & 0.640 & $a b c$ & 0.141 & d-h & 0.394 & $e-h$ \\
\hline 5 & 27.1 & e-h & 25.8 & b-e & 0.610 & b-g & 0.146 & $a-d$ & 0.401 & a-e \\
\hline 6 & 30.2 & $a b$ & 26.5 & $\mathrm{a}$ & 0.633 & a-e & 0.140 & e-h & 0.395 & d-g \\
\hline 7 & 26.4 & gh1 & 26.2 & $a b$ & 0.668 & $\mathrm{a}$ & 0.146 & $a-d$ & 0.403 & $a-d$ \\
\hline 8 & 28.3 & cde & 25.6 & e-g & 0.525 & $\mathrm{k}$ & 0.129 & $\mathrm{k}$ & 0.366 & $\mathrm{k}$ \\
\hline 9 & 30.9 & $\mathrm{a}$ & 25.4 & e-h & 0.615 & b-f & 0.147 & $a b c$ & 0.402 & a-e \\
\hline 10 & 26.1 & g-k & 25.4 & e-h & 0.589 & $f-1$ & 0.138 & $g-j$ & 0.384 & jk \\
\hline 11 & 26.9 & $f-1$ & 26.2 & $a b c$ & 0.557 & h-k & 0.143 & b-f & 0.388 & $f-1$ \\
\hline 12 & 27.8 & def & 25.2 & fgh & 0.639 & $a-d$ & 0.150 & $\mathrm{a}$ & 0.408 & $\mathrm{a}$ \\
\hline 13 & 29.3 & $\mathrm{bc}$ & 25.9 & bcd & 0.628 & b-f & 0.139 & $\mathrm{~g}-1$ & 0.396 & $c-f$ \\
\hline 14 & 28.9 & bcd & 25.4 & d-h & 0.600 & d-g & 0.138 & $\mathrm{~g}-\mathrm{j}$ & 0.386 & hij \\
\hline 15 & 21.6 & $\mathrm{n}$ & 24.6 & $1 \mathrm{j}$ & 0.551 & $1 \mathrm{jk}$ & 0.133 & $\mathrm{jk}$ & 0.383 & jk \\
\hline 16 & 24.2 & $\mathrm{~m}$ & 23.8 & $\mathrm{k}$ & 0.543 & $\mathrm{jk}$ & 0.133 & $\mathrm{jk}$ & 0.387 & $g-j$ \\
\hline 17 & 25.0 & $j-m$ & 24.5 & $\mathrm{j}$ & 0.572 & $\mathrm{~g}-\mathrm{j}$ & 0.134 & $1 \mathrm{jk}$ & 0.384 & jk \\
\hline 18 & 26.3 & $g-j$ & 25.0 & h1 & 0.613 & $b-f$ & 0.146 & $a-d$ & 0.398 & b-e \\
\hline 19 & 25.8 & $1-1$ & 25.2 & fgh & 0.603 & $c-g$ & 0.144 & $b-f$ & 0.395 & d-g \\
\hline 20 & 27.4 & efg & 25.1 & gh & 0.622 & $b-f$ & 0.141 & d-h & 0.397 & $b-f$ \\
\hline 21 & 25.9 & h-1 & 24.3 & $\mathrm{jk}$ & 0.594 & e-h & 0.138 & $g-j$ & 0.395 & d-g \\
\hline 22 & 24.7 & $\operatorname{lm}$ & 24.1 & $\mathrm{jk}$ & 0.543 & $\mathrm{jk}$ & 0.137 & hij & 0.385 & jk \\
\hline 23 & 29.1 & bcd & 25.9 & bcd & 0.643 & $a b$ & 0.148 & $a b$ & 0.405 & $a b$ \\
\hline 24 & 20.4 & $\mathrm{n}$ & 22.4 & 1 & 0.533 & $\mathrm{jk}$ & 0.136 & hij & 0.378 & $\mathrm{j}$ \\
\hline 2012-13 & 26.7 & B & 26.2 & B & 0.507 & $\mathrm{C}$ & 0.126 & $\mathrm{C}$ & 0.367 & B \\
\hline 2013-14 & 27.7 & A & 25.2 & A & 0.661 & A & 0.151 & A & 0.407 & A \\
\hline 2014-15 & 25.7 & $\mathrm{C}$ & 24.1 & $\mathrm{C}$ & 0.629 & B & 0.144 & B & 0.405 & A \\
\hline Ortalama & 26 & & 25 & & 0.60 & & 0.12 & & 0.39 & \\
\hline VK & & & 2. & & 8.2 & & 5.1 & & 2.8 & \\
\hline
\end{tabular}

* ZSD: Zeleny sedimantasyon değeri (ml); YG: Yaş gluten değeri (\%); K: Potasyom (\%); Mg; Magnezyum (\%); P: Fosfor (\%) 
Üç yılın ortalamasına göre genotiplerin nişasta oranı (NO) \% 62.4 (2 ve 5 numaralı hat) ile 66.4 (8 numaralı hat) arasında değişmiş ve ortalama NO $\% 63.4$ olmuştur. Y1lların ortalaması olarak 2012-2013, 20132014 ve 2014-2015 yetiştirme sezonlarında NO sırasıyla $\% 65.3,61.7$ ve 63.3 olarak belirlenmiştir. Tanedeki nişasta endospermin yaklaşık olarak \% 60'lık kısmını oluşturmaktadır. İklim koşulları ve genetik farklılıklardan dolayı tritikale'deki protein, yağ, kül ve nişasta içeriğindeki belirgin bir dalgalanma daha önce yapılan çalışmada bildirilmiştir (Alaru ve ark., 2003). Yapılan çalışmalarda Brand ve ark. (2003) \% 59.8 ile 63.6, Rakha ve ark. (2013) \% 63.5 ile 70.4, Kızılgeçi ve Yıldırım (2017) \% 62.5 ile 64.7 arasında değiştiğini bildirmişlerdir.

Yılların ortalamasına göre kül oranı (KO) \% 1.68 (8 numaralı hat) ile 2.17 (2 numaralı hat) arasinda değişmiştir. Yılların ortalaması olarak 2012-2013, 20132014 ve 2014-2015 yetiştirme sezonlarında sırasıyla kül oranı \% 1.80, 2.07 ve 2.01 olarak tespit edilmiştir (Çizelge 4). Brand ve ark. (2003) yaptıkları çalışmada kül oranının $\% \quad 1.5$ ile 2.3 arasında değiştiğini bildirmişlerdir.

Üç yılın ortalamasına göre ADF \% $2.43 \quad(16$ numaralı hat) ile 3.59 (24 numaralı hat) ve NDF \% 17.5 (16 numaralı hat) ile 19.1 (5 numaralı hat) arasinda değişmiştir. Ortalama ADF ve NDF değerleri sırasıyla $\% 3.02$ ve \% 18.4 olmuştur. ADF değeri bakımından 13, $16,21,22$ ve 23 numaralı, NDF değeri bakımından ise 8 ve 16 numaralı genotipler en düşük değerlere sahip olmuştur. Yılların ortalaması olarak 2012-2013, 20132014 ve 2014-2015 yetiştirme sezonlarında sırasıyla ADF \% 3.64, 2.56, 2.86 ve NDF \% 18.3, 19.3, 17.7 olarak tespit edilmiştir (Çizelge 4). ADF değerinin \% 3.6 ile 4.1 ve NDF değerinin \% 17.6 ile 21.1 (Brand ve ark., 2003), ADF değerinin \% 2.5 ile 3.1 ve NDF değerinin \% 8.0 ile 14.8 (Rakha ve ark., 2013), ADF değerinin \% 2.5 ile 2.9 ve NDF değerinin \% 10.3 ile 13.1 (Alijosius ve ark., 2016) arasında değiştiği bildirilmiştir. Asit deterjanda çözünmeyen lif (ADF) bitki hücre duvarı yapısındaki selüloz, lignin ve çözünmeyen protein miktarını gösterir. Ayrıca yemin sindirilebilirliği ve hayvanın enerji alımı hakkında da bilgi veren iyi bir göstergedir.

Çizelge 6. Özellikler arası korelasyon katsayıları ve önemlilik seviyeleri

\begin{tabular}{|c|c|c|c|c|c|c|c|c|c|c|c|c|c|c|c|c|}
\hline & $\mathrm{BB}$ & MBS & $\mathrm{HI}$ & TV & BTA & HA & $\mathrm{PO}$ & $\mathrm{YO}$ & $\mathrm{NO}$ & $\mathrm{KO}$ & $\mathrm{ADF}$ & NDF & ZSD & YG & $\mathrm{K}$ & $\mathrm{Mg}$ \\
\hline MBS & $0.190^{* *}$ & & & & & & & & & & & & & & & \\
\hline HI & $0.160^{* *}$ & $0.255^{* *}$ & & & & & & & & & & & & & & \\
\hline TV & $0.422^{* *}$ & $0.405^{* *}$ & $0.548^{* * *}$ & & & & & & & & & & & & & \\
\hline BTA & $0.240^{* *}$ & 0.076 & $0.201^{* * *}$ & $0.479^{* * *}$ & & & & & & & & & & & & \\
\hline HA & $0.192^{* *}$ & $0.214^{* * *}$ & $0.323^{* *}$ & $0.559^{* *}$ & $0.316^{* *}$ & & & & & & & & & & & \\
\hline $\mathrm{PO}$ & $-0.140^{*}$ & -0.053 & $-0.209^{* *}$ & $-0.238^{* * *}$ & ${ }^{*}-0.081$ & $-0.218^{* *}$ & & & & & & & & & & \\
\hline YO & $-0.355^{* *}$ & $-0.175^{* *}$ & $0.164^{* *}$ & $-0.126^{*}$ & -0.060 & 0.055 & $-0.169^{* *}$ & & & & & & & & & \\
\hline NO & $-0.258^{* *}$ & -0.007 & $0.382^{* *}$ & 0.106 & 0.089 & $0.327^{* *}$ & $-0.472^{* *}$ & $0.530^{* * *}$ & & & & & & & & \\
\hline $\mathrm{KO}$ & $0.202^{* * *}$ & -0.026 & $-0.262^{* *}$ & -0.001 & -0.108 & $-0.235^{* *}$ & $0.439^{* * *}$ & $-0.487^{* *}$ & $-0.821^{* * *}$ & & & & & & & \\
\hline $\mathrm{ADF}$ & $-0.402^{* *}$ & $-0.194^{* *}$ & ${ }^{*} 0.181^{* * *}$ & $-0.119^{*}$ & $-0.134^{*}$ & 0.038 & $-0.218^{* *}$ & $0.742^{* *}$ & $0.517^{* *}$ & $-0.333^{* *}$ & & & & & & \\
\hline NDF & -0.101 & -0.084 & $-0.450^{* * *}$ & $-0.566^{* *}$ & ${ }^{*}-0.514^{* *}$ & ${ }^{*}-0.565^{* *}$ & $0.319^{* * *}$ & $-0.194^{* *}$ & $-0.567^{* * *}$ & $0.444^{* *}$ & -0.023 & & & & & \\
\hline ZSD & -0.071 & $-0.196^{* *}$ & ${ }^{*}-0.340^{* *}$ & $-0.304^{* *}$ & ${ }^{*}-0.146^{*}$ & $-0.142^{*}$ & $0.442^{* *}$ & $-0.265^{* *}$ & $-0.318^{* *}$ & $0.325^{* * *}$ & $-0.202^{* *}$ & * $0.308^{* *}$ & & & & \\
\hline YG & $-0.147^{*}$ & $-0.129^{*}$ & $-0.378^{* *}$ & $-0.496^{* * *}$ & ${ }^{*}-0.321^{* * *}$ & ${ }^{*}-0.402^{* * *}$ & $0.503^{* * *}$ & $-0.309^{* *}$ & $-0.433^{* *}$ & $0.357^{* * *}$ & $-0.196^{* *}$ & $0.588^{* * *}$ & $0.708^{* * *}$ & & & \\
\hline K & $0.291^{* * *}$ & 0.075 & $-0.244^{* *}$ & 0.054 & $-0.120^{*}$ & $-0.169^{* *}$ & $0.414^{* *}$ & $-0.667^{* *}$ & $-0.818^{* *}$ & $0.860^{* * *}$ & $-0.465^{* *}$ & ${ }^{*} 0.506^{* *}$ & $0.312^{* *}$ & $0.386^{* *}$ & & \\
\hline $\mathrm{Mg}$ & $0.288^{* * *}$ & 0.073 & $-0.360^{* * *}$ & -0.019 & -0.056 & $-0.247^{* * *}$ & $0.456^{* * *}$ & $-0.585^{* *}$ & $-0.860^{* * *}$ & $0.748^{\text {*** }}$ & $-0.524^{* * *}$ & $0.522^{* *}$ & $0.313^{* *}$ & $0.408^{* * *}$ & $0.839^{* * *}$ & \\
\hline $\mathrm{P}$ & $0.349^{* *}$ & 0.080 & $-0.235^{* *}$ & $0.125^{*}$ & 0.002 & $-0.132^{*}$ & $0.458^{* * *}$ & $-0.605^{* *}$ & $-0.867^{* *}$ & $0.869^{* * *}$ & $-0.520^{* * *}$ & ${ }^{*} 0.380^{* * *}$ & $0.254^{* * *}$ & $0.291^{* * *}$ & $0.912^{* * *}$ & $0.887^{* * *}$ \\
\hline
\end{tabular}

${ }^{*} \mathrm{p}<0.05$ ve ${ }^{* *} \mathrm{p}<0.01$ düzeyinde önemlidir. BB: Bitki boyu (cm); MBS: Metrekaredeki başak sayısı (adet); HI: Hasat indeksi (\%);TV: ttane verimi $\left(\mathrm{kg} \mathrm{da}^{-1}\right)$; BTA: Bin tane ağırlığı (g); HA: Hektolitre ağırlığı (kg); PO: Protein oranı (\%); YO: Yağ oranı (\%); NO: Nişasta oranı (\%); KO: kül oranı (\%); ADF: Asit deterjanda çözünmeyen lif (\%); NDF: Nötr deterjanda çözünmeyen lif (\%), SD: Sedimentasyon değeri (ml); YG: Yaş gluten değeri (\%); K: Potasyom (\%); Mg; Magnezyum (\%); P: Fosfor (\%)

Yüksek ADF içeren yemlerin sindirilebilirliği ve enerji değeri düşüktür (Kutlu, 2008). Nötr deterjanda çözünmeyen lif (NDF) bitki hücre duvarı yapısında bulunan selüloz, hemiselüloz, lignin, kütin ve çözünmeyen protein miktarını ifade eder. NDF değeri hayvanların yem alımına doğrudan etkili olduğundan, yemde bu değer düştükçe hayvanın yem alımı artar (Van Soest ve ark., 1991).

Genotiplerin ortalama Zeleny sedimantasyon değeri (ZSD) 20.4 (24 numaralı hat) ile $30.9 \mathrm{ml}$ (9 numaralı hat) arasında ve yaş gluten (YG) değeri \% 22.4 (24 numaralı hat) ile 26.5 (6 numaralı hat) arasinda değişmiştir. ZSD 1, 6 ve 9 numaralı genotiplerde, YG değeri ise 6,7 ve 11 numaralı genotiplerde daha yüksek bulunmuş ve istatistiki olarak aynı grupta yer almışlardır. 2012-2013, 2013-2014 ve 2014-2015 yetiştirme sezonlarında sırasıyla ZSD 26.7, 25.7, 27.7 $\mathrm{ml}$ ve YG değeri \% 26.2, 25.2, 24.1 olarak tespit edilmiştir (Çizelge 5). Protein miktarı ve kalitesini belirlemede kullanılan önemli yöntemlerden birinin de 
sedimantasyon değeri olduğu bilinmektedir. Sedimantasyon değeri arttıkça ekmek hacmi de artmaktadır. Gluten içeriği, özellikle hamurun yoğurma, işlenme özellikleri, gaz tutma kapasitesi ve son ürün kalitesi üzerine etkilidir. Tritikale genotipleri ile yapılan çalışmada; sedimantasyon değerlerinin $16.84-20.17 \mathrm{ml}$ arasında olduğu ve gluten'in ise elde edilemediği belirtilmiş, bu durumun tritikale tanelerinin yeterli protein içermelerine karşılık öz kalitelerinin zayıf olmasından kaynaklandığı bildirilmiştir (Çif̧̧i ve ark., 2010). Grausgruber ve ark. (2000), Zeleny sedimentasyon değerinin kalıtım etkisi altında olduğunu daha çok çeşitten etkilendiğini bildirmişlerdir. Bazı araştırıcılar da tanedeki sedimantasyon ve gluten içeriğinin yıllara ve çevre koşullarına göre farklılıklar gösterdiğini rapor etmişlerdir (Çifçi ve ark., 2010; Tayyar ve Kahrıman., 2016; Kızılgeçi ve ark., 2017; Kızılgeçi ve Yıldırım, 2017).

Üç yılın ortalamasına göre K \% 0.525 (8 numaralı hat) ile 0.668 (7 numaralı hat), $\mathrm{Mg} \% 0.129$ (8 numaralı hat) ile 0.150 (12 numaralı hat), P \% 0.366 (8 numaralı hat) ile 0.408 (12 numaralı hat) arasında değişmiştir. Ortalama K, Mg ve P sirasiyla \% 0.606, 0.145, 0.398 olmuştur. Y1lların ortalaması olarak 2012-2013, 20132014 ve 2014-2015 yetiştirme sezonlarında sırasıyla $K$ $\% 0.507,0.661,0.629, \mathrm{Mg} \% 0.126,0.151,0.144$ ve $\mathrm{P}$ $\%$ 0.367, 0.407, 0.405 olarak tespit edilmiştir (Çizelge 5). Daha önceki yıllarda yapılan çalışmalarda $\mathrm{K}, \mathrm{Mg}$ ve $\mathrm{P}$ değerlerinin çeşitlere göre farklılık gösterdiği bir çok araştırıcı tarafindan bildirilmiş̦tir (Pena, 2004; Myer ve Lozano, 2004; Poutanen, 2012; Jakobsone ve ark., 2015).

Araştırmada incelenen özelliklere ilişkin üç yıllık sonuçlardan hesaplanan korelasyon katsayıları ve biplot grafiği Çizelge 6 ve Şekil 1'de verilmiştir. Yapılan korelasyon analizine göre, tritikale genotiplerinde TV ile BB $\left(\mathrm{r}=0.422^{* *}\right)$, MBS $\left(\mathrm{r}=0.405^{* *}\right)$, HI $\left(\mathrm{r}=0.548^{* *}\right)$, BTA $(r=0.479 * *)$, HA $\left(r=0.559^{* *}\right)$ ve $\mathrm{P}\left(\mathrm{r}=0.129^{*}\right)$ arasında önemli ve olumlu, $\mathrm{PO}\left(\mathrm{r}=-0.238^{* *}\right)$, YO $(\mathrm{r}=-$ $\left.0.126^{*}\right), \operatorname{ADF}\left(\mathrm{r}=-0.119^{*}\right), \mathrm{NDF}\left(\mathrm{r}=-0.566^{* *}\right), \mathrm{ZSD}$ $\left(\mathrm{r}=-0.304^{* *}\right)$ ve $\mathrm{YG}\left(\mathrm{r}=-0.496^{* *}\right)$ arasında önemli ve olumsuz ilişki tespit edilmiştir (Çizelge 6). Yapılan çalışmalarda TV ile BTA ve MBS arasında (Furan ve ark., 2005), TV ile BTA ve HA arasında (Doğan ve Şenyiğit, 2016) olumlu ve önemli ilişki olduğu bildirilmiştir.

BB ile MBS $\left(\mathrm{r}=0.190^{* *}\right)$, HI $\left(\mathrm{r}=0.160^{* *}\right)$, BTA $(\mathrm{r}=0.240 * *), \mathrm{HA} \quad(\mathrm{r}=0.192 * *), \mathrm{KO} \quad(\mathrm{r}=0.202 * *), \mathrm{K}$ $\left(\mathrm{r}=0.291^{* *}\right), \mathrm{Mg}\left(\mathrm{r}=0.288^{* *}\right)$ ve $\mathrm{P}\left(\mathrm{r}=0.349^{* *}\right)$ arasinda önemli ve olumlu, PO $\left(\mathrm{r}=-0.140^{*}\right)$, YO $\left(\mathrm{r}=-0.355^{* *}\right)$, NO $\left(r=-0.258^{* *}\right)$, ADF $(r=-0.402 * *)$ ve YG $(r=-$ $0.147^{*}$ ) arasında önemli ve olumsuz ilişki belirlenmiştir. BTA ile HI $\left(\mathrm{r}=0.201^{* *}\right)$, HA $\left(\mathrm{r}=0.316^{* *}\right)$ arasinda önemli ve olumlu, ADF ( $\mathrm{r}=-0.134 *)$, NDF ( $\mathrm{r}=$ $0.514 * *), Z S D\left(r=-0.146^{*}\right), Y G\left(r=-0.321^{* *}\right)$ ve $\mathrm{K}(\mathrm{r}=$ $\left.-0.120^{*}\right)$ arasında önemli ve olumsuz ilişki tespit edilmiştir. PO ile KO $\left(\mathrm{r}=0.439^{* *}\right)$, NDF $\left(\mathrm{r}=0.319^{* *}\right)$, ZSD ( $\left.\mathrm{r}=0.442^{* *}\right), \mathrm{YG}(\mathrm{r}=0.503 * *), \mathrm{K}\left(\mathrm{r}=0.414^{* *}\right), \mathrm{Mg}$ $\left(\mathrm{r}=0.456^{* *}\right)$ ve $\mathrm{P}\left(\mathrm{r}=0.458^{* *}\right)$ arasinda önemli ve olumlu, HI $\left(\mathrm{r}=-0.209^{* *}\right)$, HA $\left(\mathrm{r}=-0.218^{* *}\right), \mathrm{YO}(\mathrm{r}=-$ $\left.0.169^{* *}\right)$, NO $(\mathrm{r}=-0.472 * *)$ ve $\mathrm{ADF}\left(\mathrm{r}=-0.218^{* *}\right)$ arasında önemli ve olumsuz ilişki belirlenmiştir (Çizelge 6). Konu ile ilgili çalışmalarda benzer sonuçlar elde edilmiştir (Akgün ve Altındal, 2011; Goyal ve ark., 2011; Oral ve Ülker, 2016).

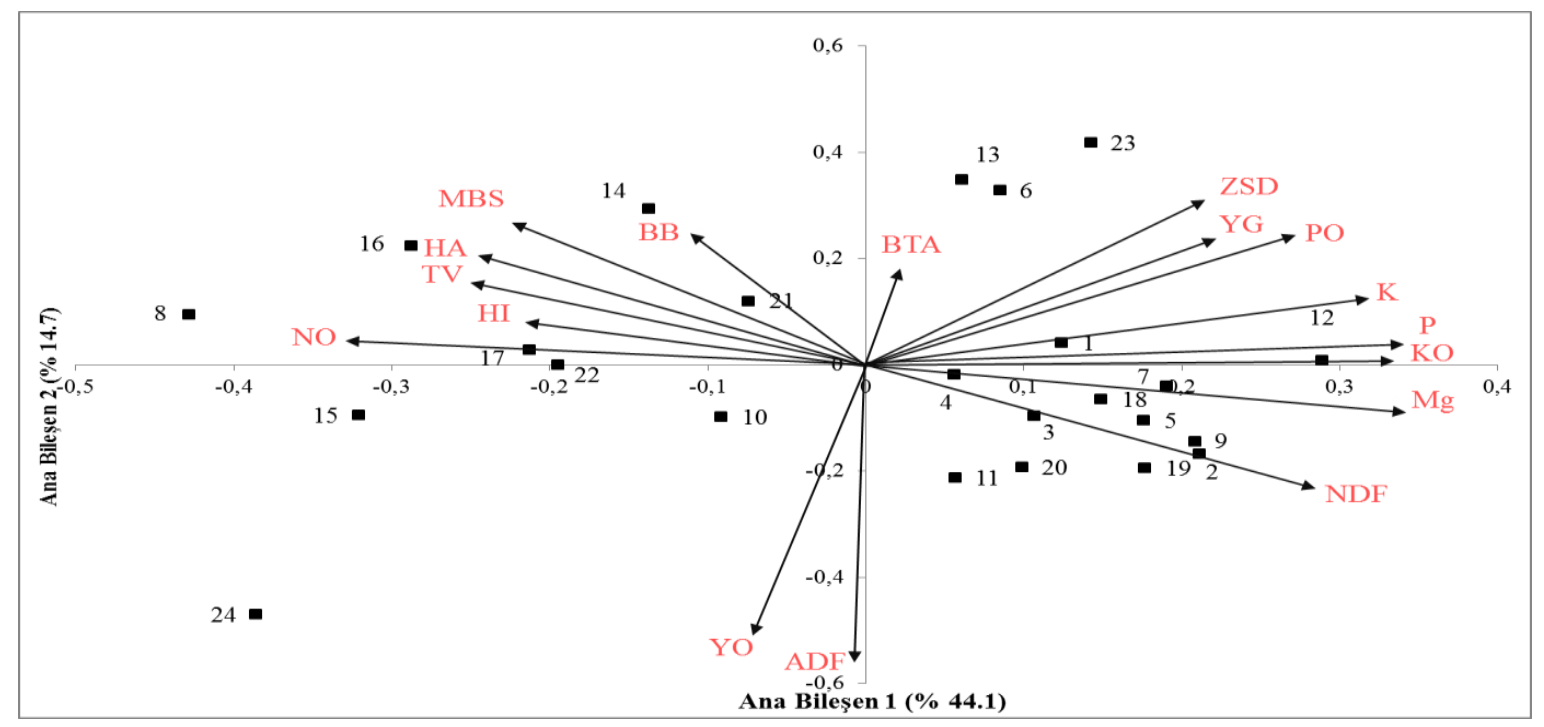

Şekil 1. İncelenen özelliklerin Biplot analiz yöntemi ile gruplandırılması ve genotiplerin incelenen özelliklerle olan ilişkisi

Genotip ve özellikler arasındaki ilişkileri bir bütün olarak gösteren biblot analizi, yalnızca iki özellik arasındaki ilişkiyi gösteren korelasyon analizine göre üstünlükleri vardır (Yan ve Reid, 2008). Çalışmada incelenen özelliklerin genotiplere göre sinıflandırılması ve genotiplerin özelliklere göre değişimi Şekil 1'de verilmiştir. Biplot analizinde Ana bileşen $1 \% 44.1$ ve Ana bileşen $2 \quad \% \quad 14.7$ olmak üzere toplamda 
varyasyonun \%58.8'ini oluşturmuştur (Şekil 1). Şekil 1 'de görüldüğü gibi ele alınan özelliklerden $\mathrm{BB}$, MBS, HA, TV, HI ve NO'ya ait vekörler aynı yönde, YO ve ADF'ye ait vektörler aynı yönde, ZSD, YG, PO, K, P, $\mathrm{KO} \mathrm{Mg}$ ve NDF değerine ait vektörler aynı yönde yer almıştır. Tane verimi bakımından yüksek olan 14, 15, 17 ve 24 numaralı genotiplerden, 14 numaralı genotip HI, HA, MBS ve NO bakımından, 15 numaralı genotip BB, MBS, HI, NO, YO ve ADF bakımından, 17 numaralı genotip BB, MBS, HI ve NO bakımından, 24 numaralı genotip ise BB, MBS, HA, YO, ve ADF bakımından da ön plana çıkmıştır (Şekil 1). 23 numaralı genotip tane verimi yanında; BB, BTA, ZSD, YG, PO, $\mathrm{K}, \mathrm{P}$ ve $\mathrm{Mg}$ gibi özellikler bakımından da yüksek değer göstermiştir (Şekil 1). Merkeze doğru yaklaşan hatlardan 4,10 ve 21 numaralı genotipler birden fazla özellik açısından öne çıkarken, genel ortalama değerleri bir özellik açısından öne çıkan genotiplere göre daha düşük olmuştur. Şekil 1'de görüldüğü gibi aynı grupta yer alan özellikler arasında yapılan korelasyon analizinde de bu özellikler arasındaki ilişkinin $\% 1$ ve \% 5 düzeylerinde önemli ve olumlu olduğu belirlenmiştir (Çizelge 5). Özellikle yüksek sıcaklıklar ve yetersiz yağış nedeni ile kuru tarım yapılan bölgelerde yetiştirilen tahıllarda kalite unsurları yönünden önemli değişimler olabilmektedir (Karnoven ve ark., 1991). Bundan dolayı, kalite özelliklerinin birbirleriyle ve tane verimi ile olan ilişkileri iklimsel şartlara bağlı olarak değişim gösterebilmektedir (Goyal ve ark., 2011; Mut ve ark., 2017).

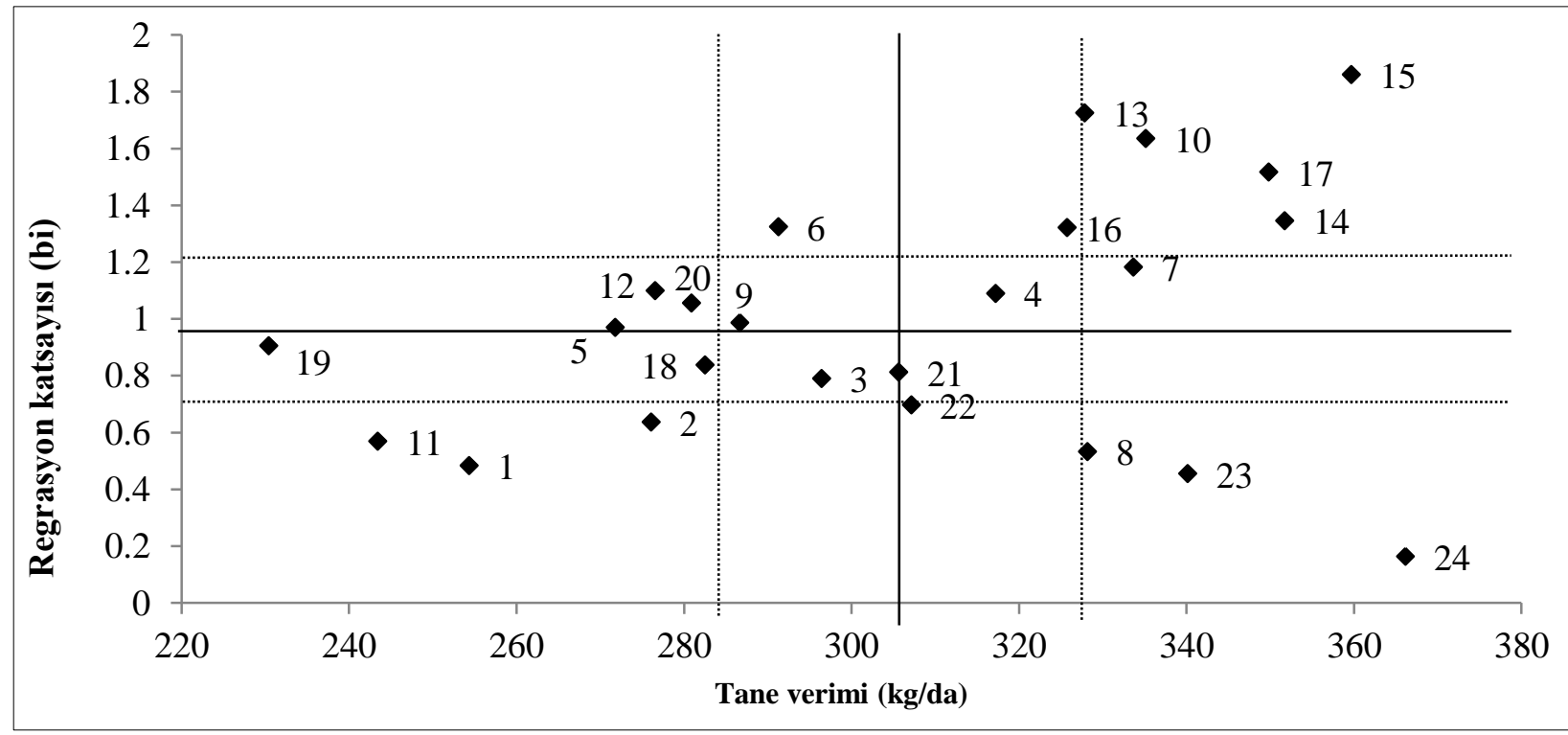

Şekil 2. Farklı yıllarda yetiştirilen tritikale genotiplerinin tane verimine ait regresyon katsayısı ve deneme ortalamalarına göre stabilite durumlar

Ayrıca, bu çalışmada 24 Tritikale genotipinin 3 yılın ortalama tane verimi üzerinden tahmin edilen stabilite parametresi olan regresyon katsayısı (bi) ve ortalama tane verimi değerleri dikkate alınarak stabilite analizi yapılmıştır. Regresyon katsayısı 1'e eşit ve ortalama verimi genel ortalamaya eşit ya da üstünde olan genotipler ideal olarak kabul edilmektedir. Ayrıca, bi değerinin 1'den küçük olması genotiplerin kötü koşullara, bi değerinin 1 'den büyük olması ise genotiplerin iyi çevre şartlarına uyum gösterebileceğini göstermektedir. Bu çalışmada genotiplerin regresyon katsayısi ve ortalama tane verimleri kullanılarak oluşturulan grafikle genotiplerin uyum yetenekleri değerlendirilmiştir (Şekil 2).

Denemede yer alan genotipler regresyon katsayıları yönünden değerlendirildiğinde "bi" değeri 1'e eşit ve ortalama verimi genel ortalamadan yüksek olan 7 numaralı genotip bütün çevrelere iyi adaptasyon göstermiştir. Regresyon katsayısı (bi) değeri 1'e eşit ve genotip ortalaması genel ortalamaya eşit olan 3, 4, 9 ve
21 numaralı genotipler bütün çevrelere orta derecede adaptasyona sahip olmuştur. Çalışmada bi değeri 1'e eşit olan ve ortalama verimleri genel ortalamadan düşük olan $5,12,18,19$ ve 20 numaralı genotipler bütün çevrelere kötü adaptasyon göstermiştir. 10, 13, 14, 15, 16 ve 17 numaralı genotipler 1'den büyük bi değeri ve genel ortalamanın üstünde tane verimleri ile iyi çevrelere özel adaptasyon gösteren genotipler olmuştur. 8,23 ve 24 numaralı genotipler 1'den küçük bi değeri ve genel ortalamanın üstünde tane verimleri ile kötü çevrelere özel adaptasyon gösteren genotipler olmuşlardır. Regresyon katsayısı (bi) değeri 1'den küçük ve genotip ortalaması genel ortalamadan düşük olan 1, 2 ve 11 numaralı genotipler kötü çevrelere kötü adaptasyon göstermiştir.

\section{Sonuç}

Marjinal tarım alanlarında daha yüksek verim almak amacıyla geliştirilen tritikalede verim incelenen 
özellikler içerisinde en önemli ıslah amacıdır. Ancak, günümüzde tek başına verimin yeterli olmadığı bunun yanında kullanım amacına göre bazı kalite özellikleri ile verimin birlikte değerlendirilmesi gerekliliği vardır. Çalışmada ele alınan özellikler verim ile kaliteyi birlikte değerlendirmede kullanılan en önemli özelliklerdir. Yozgat koşullarında üç yıl boyunca yürütülen bu çalışmada; çeşitlerin ortalama tane verimleri 230.4 $366.1 \mathrm{~kg} \mathrm{da}^{-1}$ arasında değişmiş, en yüksek tane verimi sirasiyla $24\left(366.1 \mathrm{~kg} \mathrm{da}^{-1}\right), 15\left(359.7 \mathrm{~kg} \mathrm{da}^{-1}\right), 14$ $\left(351.7 \mathrm{~kg} \mathrm{da}^{-1}\right), 17\left(349.8 \mathrm{~kg} \mathrm{da}^{-1}\right)$ ve $23\left(340.2 \mathrm{~kg} \mathrm{da}^{-1}\right)$ numaralı genotiplerden elde edilmiştir. Biplot analiz grafiğine göre, tane verimi de yüksek olan genotiplerden, 14 numaralı genotip HI, HA, MBS ve NO bakımından, 15 numaralı genotip BB, MBS, HI, NO, YO ve ADF bakımından, 17 numaralı genotip BB, MBS, HI ve NO bakımından, 24 numaralı genotip BB, MBS, HA, YO ve ADF bakımından da ön plana çıkmışır. 23 numaralı genotip ise tane verimi yanında; $\mathrm{BB}, \mathrm{BTA}, \mathrm{ZSD}, \mathrm{YG}, \mathrm{PO}, \mathrm{K}, \mathrm{P}$ ve $\mathrm{Mg}$ gibi özellikler bakımından ön plana çıkmıştır. Bunun yanında stabilite analizine göre tane verimi bakımından 7 numaralı genotip tüm çevrelere iyi uyum, 3, 4, 9 ve 21 numaralı genotipler tüm çevrelere orta uyum göstermiştir.

\section{Teşekkür}

Bu çalışma, Bozok Üniversitesi Bilimsel Araştırma Projeleri Destekleme Birimi tarafindan 2014ZF/A106 numaralı proje ile desteklenmiştir.

\section{Kaynaklar}

AACC, American Association of Cereal Chemists., 2005. Approved Methods of the AACC (11th ed.). St. Paul, USA.

Akgün, İ., Altındal, D., 2011. Bazı tritikale genotiplerinde tane verimi ve stabilite analizi. Süleyman Demirel Üniversitesi Ziraat Fakültesi Dergisi, 6(1): 7-14.

Akgün, İ., Kaya, M., Altındal, D., 2007. Isparta ekolojik koşullarında bazı tritikale hat/çeşitlerinin verim ve verim unsurlarının belirlenmesi. Akdeniz Üniversitesi Ziraat Fakültesi Dergisi, 20(2): 171- 182.

Akgün, İ., Tosun, M., Sağsöz, S., 1997. Erzurum ekolojik koşullarında bazı tritikale hat ve çeşitlerinin verim ve verim unsurları üzerine bir araştırma. Atatürk Üniv. Zir. Fak. Derg., 28(1), 103-119.

Alaru, M., Laur, Ü., Jaama, E., 2003. Influence of nitrogen and weather conditions on the grain quality of winter triticale. Agronomy Research, 1: 3-10.

Albayrak, S., Mut, Z., Töngel, Ö., 2006. Tritikale (X Triticosecale Wittmack) hatlarında kuru ot ve tohum verimi ile bazı tarımsal özellikler. Süleyman Demirel Üniversitesi Ziraat Fakültesi Dergisi, 1(1): 13-21.

Alijosius, S., Avirmickas, G.J., Bliznikas, S., Gruzauskas, R., Sasyte, V., Raceviciute-Stupeliene, A., Kliseviciute, V., Dauksiene, A., 2016. Grain chemical composition of different varieties of winter cereals. ZemdirbysteAgriculture, 103(3): 273-280.

Alp, A., 2009. Diyarbakır kuru koşullarında bazı tescilli tritikale (XTriticosecale Wittmack) çeşitlerinin tarımsal özelliklerinin belirlenmesi. YYÜ Tar. Bil. Derg., 19(2): 61-70.

Atak, M., 2004. Farklı Triticale hatlarının morfolojik ve DNA markörleriyle genetik karaketerizasyonu. Doktora Tezi, A.Ü. Fen Bil. Enst. Ankara.

Atak, M., Çiftçi, C.Y., 2006. Bazı tritikale çeşit ve hatlarının morfolojik karakterizasyonu. Tarım Bilimleri Dergisi, 12(1): 101-111.

Beres, B.L., Harker, K.N., Clayto, G.W., Bremer, E., Blacksha, R.E., Graf, R.J., 2010. Weed competitive ability of spring and winter cereals in the Northern Great Plains. Weed Technol. 24: 108-116.

Brand, T.S., Cruywagen, C.W., Brandt, D.A., Viljoen, M., Burger, W.W. 2003. Variation in the chemical composition, physical characteristics and energy values of cereal grains produced in the western cape area of South Africa. South African Journal of Animal Science, 33(2): 117-126.

Çifçi, A.E., Kınabaş, S., Yelbey, S., Yağdı, K., 2010. Bazı tritikale hatlarının kalite özellikleri ve ekmek yapımında kullanılma olanaklarının araştırılması. Uludağ Üniversitesi Ziraat Fakültesi Dergisi, 24(2): 93-102.

Doğan, R. Senyigit, E. 2016. Correlation and Path coefficient analysis of yield and yield components in hexaploid triticale (X Triticosecale Wittmack) genotypes under mediterranean conditions. J. Biol. Environ. Sci., 10(28): 21-27.

Elgün, A., Türker, S., Bilgiçli, N., 2001. Tahıl ve ürünlerinde analitik kalite kontrolü. Konya Ticaret Borsası Yayın No: 2, Konya.

FAO,

2014. http://faostat.fao.org/site/567/DesktopDefault.aspx?Page $\mathrm{ID}=567$ \#ancor (Erişim tarihi: 02 Ağustos 2017).

Finlay, K.W., Wilkinson, G.N., 1963. The analysis of adaptation in a plant breeding programme. Austral. J. Agric. Res. 14: 742-754.

Furan, M.A., Demir, İ., Yüce, S., Akçalı Can, R. R., Aykut, F., 2005. Ege Bölgesi tritikale çeşit geliştirme çalışmaları; geliştirilen çeşit ve hatların verim ve kalite özellikleri üzerinde araştırmalar. Akdeniz Üniversitesi Ziraat Fakültesi Dergisi, 18(2): 251-256.

Geren, H., Soya, H., Ünsal, R., Kavut, Y.T., Sevim, İ, Avcioglu, R., 2012. Investigations on the grain yield and other yield characteristics of some triticale cultivars grown under Menemen conditions. J. Agric. Fac. Ege Univ. 49(2): 195- 200.

Goyal, A., Beres, B.L., Randhawa, H.S., Navabi, A., Salmon, D.F., Eudes, F., 2011. Yield stability analysis of broadly adaptive triticale germplasm in southern and central Alberta, Canada, for industrial end-use suitability. Can. J. Plant Sci., 91:125-135.

Grausgruber, H., Oberforster, M., Werteber, M., Ruckenbauer, P., Volmann, J., 2000. Stability of quality traits in austrian-grown winter wheats. Field Crops Research, 66 (3): 257- 267.

Jakobsone, I., Kantane, I., Zute, S., Jansone, I., Bartkevies, V., 2015. Macro-elements and trace elements in cereal grains cultived References in Latvia. Proceeding of the Latvian Academy of Science, Section B, 69: 152-157.

Karnoven, T., Peltonen, J., Kivi, E., 1991. The effect of northern climate conditions on sprouting damage of wheat grains. Acta Agric. Scand. 41: 55-64.

Kendal, E., Sayar, M.S., 2016. The stability of some spring triticale genotypes using biplot analysis. The Journal of Animal \& Plant Sciences, 26(3): 754-765. 
Kızılgeçi, F., Akıncı, C., Albayrak, Ö., Yıldırım, M., 2017. Tritikale hatlarında bazı fizyolojik parametrelerin verim ve kalite özellikleriyle ilişkilerinin belirlenmesi. Iğdır Üni. Fen Bilimleri Enst. Der., 7(1): 337-345.

Kızılgeçi, M., Yıldırım, F., 2017. Bazı tritikale (X Triticosecale Wittmack) genotiplerinin verim ve kalite özelliklerinin belirlenmesi. Turk J Agric Res, 4(1): 4349.

Kutlu, H.R., 2008. Yem değerlendirme ve analiz yöntemleri. Çukurova Üniversitesi Ziraat Fakültesi Zootekni Bölümü, Ders Notu, Adana.

Kutlu, İ., Kınaci, G., 2011. Sulu ve kuru koşullara uygun tritikale genotiplerinde tarımsal özelliklerin belirlenmesi. Anadolu Üniversitesi Bilim ve Teknoloji Dergisi-C, Yaşam Bilimleri ve Biyoteknoloji, 1(1): 7182.

Kün, E., 1996. Tahıllar I. Ankara Üniv. Ziraat Fak. Ders Kitabi: 431, Yayın No:1451, Ankara.

Lipkovich, İ., Smith, E.P., 2002. Biplot and singular value decomposition macros for excel. Department of Statistics Virginia Tech Blacksburg, VA 24061-0439. http://www.jstatsoft.org/v07/i05/paper (Erişim tarihi: 3 Ocak 2017).

Mut, Z., Albayrak, S., Töngel, Ö., 2006. Tritikale (X Triticosecale Wittmack) hatlarının tane verimi ve bazı özelliklerinin belirlenmesi. Ankara Üniversitesi Ziraat Fakültesi Tarım Bilimleri Dergisi, 12(1): 56- 64.

Mut, Z., Erbaş Köse, Ö. D., Akay, H. 2017. Bazı ekmeklik buğday (Triticum aestivum L.) çeşitlerinin tane verimi ve kalite özelliklerinin belirlenmesi. Anadolu Tarım Bilim. Derg, 32: 85-95.

Myer, R.O., Lozano, A.J., 2004. Triticale in livestock production. In Triticale Improvement and Production, M. Mergoum (Eds.), Rome, Italy: FAO, pp 49-58.

Oettler, G., 2005. The fortune of a botanical curiosity-triticale: past, present and future. J. Agric. Sci. 143: 329-346.

Oral, E., Ülker, M., 2016. Tritikale (X Triticosecale Wittmack) çeşitlerinde özellikler arası ilişkiler ve path analizi. Iğdır Üni. Fen Bilimleri Enst. Der., 6(3): 153160.
Pena, R.J. 2004. Food uses of triticale. In: Mergoum, M. and Go'mez-Macpherson H. (eds.). Triticale improvement and production. FAO, Plant Production and Protection Paper No. 179. Food and Agriculture Organization of United Nations, Rome. pp. 37-48.

Poutanen, K., 2012. Past and future of cereal grains as food for health. Trends in Food Science and Technology, 25(2): 58-62.

Rakha, A., Aman, P., Andersson, R., 2013. Rheological characterisation of aqueous extracts of triticale grains and its relation to dietary fibre characteristics. J Cereal Sci., 57: 230-236.

SAS Institute., 1998. INC SAS/STAT users' guide release 7.0, Cary, NC, USA.

Tayyar, Ş., Kahrıman, F., 2016. Biga şartlarında yetiştirilen tritikale genotiplerinin verim ve bazı kalite özelliklerinin belirlenmesi. Adnan Menderes Üniversitesi Ziraat Fakültesi Dergisi, 13: 17-22.

TÜİK, 2016. http://tuikapp.tuik.gov.tr/bitkiselapp/bitkisel.zul (Erişim tarihi 02 Ağustos 2017).

Ünver, S., 1999. Bazı tritikale hatlarında verim ve verim öğelerinin incelenmesi. Tarla Bitkileri Merkez Araş. Ens. Der., 8: 82-92.

Van Soest, P.J., Robertson, J.B., Lewis, B.A., 1991. Methods for dietary fiber, neutral detergent fiber, and nonstarch polysaccharides in relation to animal nutrition. J. Dairy Sci., 74(10): 3583-3597.

Villegas, D., Casadesus, J., Atienza, S., Martos, V., Maalouf, F., Karam, F., Aranjuelo, I., Nogues, S., 2010. Tritordeum, wheat and triticale yield components under multi-local Mediterranean drought conditions. Field Crops Res., 116: 68-74.

Yan W, Reid JF., 2008. Breeding Line Selection Based on Multiple Traits. Crop Sci 48: 417-423.

Yanbeyi, S., Sezer, İ., 2006. Samsun koşullarında bazı tritikale hatlarının verim ve verim öğeleri üzerine bir araştırma. Ondokuz Mayıs Üniversitesi, Ziraat Fakültesi Dergisi, 21(1): 33-39. 